\title{
Dynamics of bisphenol A (BPA) and bisphenol S (BPS) in the European paper cycle: Need for concern?
}

\author{
Pivnenko, Kostyantyn; Laner, David; Astrup, Thomas Fruergaard
}

Published in:

Resources, Conservation and Recycling

Link to article, DOI:

10.1016/j.resconrec.2018.01.021

Publication date:

2018

Document Version

Peer reviewed version

Link back to DTU Orbit

Citation (APA):

Pivnenko, K., Laner, D., \& Astrup, T. F. (2018). Dynamics of bisphenol A (BPA) and bisphenol S (BPS) in the European paper cycle: Need for concern? Resources, Conservation and Recycling, 133, 278-287. https://doi.org/10.1016/j.resconrec.2018.01.021

\section{General rights}

Copyright and moral rights for the publications made accessible in the public portal are retained by the authors and/or other copyright owners and it is a condition of accessing publications that users recognise and abide by the legal requirements associated with these rights.

- Users may download and print one copy of any publication from the public portal for the purpose of private study or research.

- You may not further distribute the material or use it for any profit-making activity or commercial gain

- You may freely distribute the URL identifying the publication in the public portal 


\section{DYNAMICS OF BISPHENOL A (BPA) AND BISPHENOL S (BPS) IN THE EUROPEAN PAPER CYCLE: NEED FOR CONCERN?}

Kostyantyn Pivnenko ${ }^{\mathrm{a}_{*}}$; David Laner ${ }^{\mathrm{b}}$; Thomas F. Astrup ${ }^{\mathrm{a}}$

${ }^{a}$ Department of Environmental Engineering, Technical University of Denmark, DK-2800 Kgs. Lyngby, Denmark

${ }^{\mathrm{b}}$ Institute for Water Quality, Resources and Waste Management, TU Wien, Karlsplatz 13, 1040 Wien, Austria

"NOTE: this is the author's version of a work that was accepted for publication in Resources, Conservation \& Recycling journal. Changes resulting from the publishing process, such as peer review, editing, corrections, structural formatting, and other quality control mechanisms may not be reflected in this document. Minor changes may have been made to this manuscript since it was accepted for publication. A definitive version is published in Resources, Conservation \& Recycling journal (133C (2018) pp. 278-287)”. 


\section{Abstract}

Bisphenol A (BPA) is an industrial chemical used as an additive in conventional point-of-sale thermal paper receipts. Due to BPA being an endocrine disruptor and a substance of very high concern, the European Union (EU) has proposed to ban its use in thermal paper from 2020. Potential similarities in toxicological profiles have raised concerns that the use of bisphenol S (BPS) as a substitute for BPA may result in yet another situation of a problematic chemical being distributed in consumer products. This study provides a comprehensive evaluation of the current knowledge of BPA and BPS use in thermal paper and, based on dynamic material and substance flow modeling, quantifies potential effects of the BPA ban on future BPA and BPS flows within the European paper cycle. Based on available data and the modeling of BPA and BPS flows, approximately 200 tonnes of BPS are estimated to be present in the current European paper cycle. The modeling further demonstrated that by substituting 50\% of BPA, BPS amounts in the European paper cycle would increase more than fivefold over a modeling period of 60 years. In the same time, more than 90 tonnes of BPA would still be circulated in European paper products. BPA alternatives other than BPS should receive additional attention, as very limited quantitative data currently exist. The results of this study quantitatively demonstrate that chemical bans alone are not sufficient to ensure clean material cycles, and so the effective regulation of potential substitutes needs to be implemented in parallel.

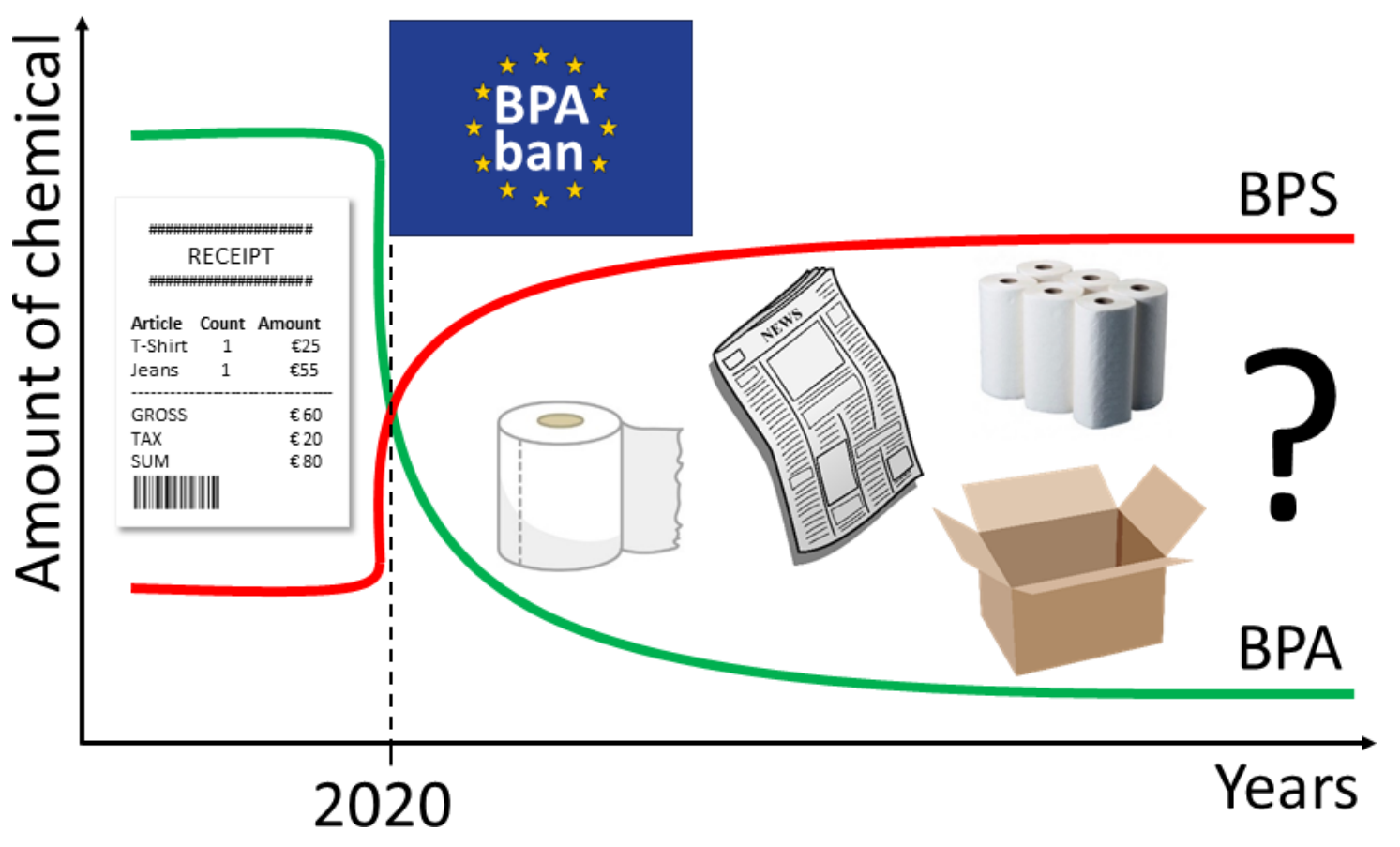




\section{Introduction}

Bisphenol A (BPA) is an industrial chemical with global annual production surpassing 6,000,000 tonnes in 2012 and anticipated growth in production of approximately 30\% by 2020. BPA is used in a variety of applications, resulting in its use by a number of industries and its presence in material exchange between numerous sectors of economy (Jiang et al., 2017). BPA is primarily used as monomer in polymer production (i.e. polycarbonate or epoxy resins), used in manufacturing of plastic products (e.g. water bottles, food containers, polycarbonate "glass”) or applied as coating (e.g. protective layer in tin cans). In addition, BPA is applied in form of an additive (developer) in thermal paper production, where it is used in its “free” (non-reacted) form. Developers in thermal paper are used in paper coating and react with heat sources by changing color and resulting in image development without the use of inks as in conventional printing (US EPA, 2014). Thermal paper is used primarily in conventional receipts in the retail sector (e.g. shop or supermarket receipts, ATM slips), potentially leading to human (consumer and professional) exposure to BPA through handling (Geens et al., 2011; Hehn, 2016; von Goetz et al., 2017). The majority of BPA present in paper material and products comes from its use in thermal paper, while BPA can potentially be used in ink and glue formulations (in form of e.g. bisphenol A diglycidyl ether (BADGE)) also applied on paper (Pivnenko et al., 2016a). Once BPA-containing paper is recycled, some BPA will be removed (primarily as paper sludge) during paper re-processing, while a fraction thereof may remain in the recycled materials and contaminate new paper products (Liao and Kannan, 2011a; Pivnenko et al., 2016a; Pivnenko et al., 2015b). Widespread use of BPA in conventional consumer products with high degree of potential exposure, and its endocrine-disrupting (hormonal) effects on living organisms, have led to gradual restrictions on BPA use and imports of selected BPA-containing products in parts of Europe, Asia, and the US (EU, 2011; NITE, 2003; State of Connecticut, 2013). Moreover, in June 2017, the Member State Committee of the European Chemicals Agency (ECHA) recognised BPA as an endocrine disruptor and a substance of very high concern (SVHC) (ECHA, 2017), leading to anticipated further restrictions on its use.

European paper production is a well-established example of an effective material recycling system in which about half of raw material needs originate from recycled fibers (CEPI, 2013). To ensure clean material flows and safe recycling, "problematic” chemical substances in the recycled materials should be limited (Pivnenko and Astrup, 2016). Recent literature has demonstrated that the selective recycling of "clean" material fractions, or the improved removal of substances during reprocessing, 
may not be sufficient to ensure BPA-free paper products without compromising quantitative recycling rates (Pivnenko et al., 2016a). Substance phase-out was therefore considered necessary.

In December 2016, the EU decided to set a maximum concentration limit of $200 \mu \mathrm{g}$ of BPA per gram of thermal paper by 2020, effectively phasing out BPA use in thermal paper (EC, 2016a). While no substitution strategies have been proposed, existing and potential alternatives to BPA have been suggested (e.g. Pivnenko et al., 2015b; US EPA, 2014). There is a number of BPA alternatives that are already in use or can potentially substitute BPA in thermal paper, including phenol-based (e.g. bisphenol S (BPS), bisphenol E (BPE), bisphenol F (BPF)) and phenol-free (e.g. Pergafast ${ }^{\circledR}$ and urea urethane) chemical compounds. Several of the proposed BPA substitutes are chemical analogues to BPA with similar molecular structures (Usman and Ahmad, 2016). Recent research has reported that some BPA substitutes have equal or even greater toxicological effects, with endocrine disrupting mechanism of action similar to that of BPA (Chen et al., 2016; Eladak et al., 2015; Kinch et al., 2015; Usman and Ahmad, 2016). BPS is a prominent example of a BPA substitute (Pivnenko et al., 2015b; US EPA, 2014). It is a structural analog to BPA with similar in vitro metabolism, potencies, and mechanisms of action (Rochester and Bolden, 2015). In addition, it has reported adverse effects in humans and rodents (Eladak et al., 2015), aligned with a number of health hazards (Rochester and Bolden, 2015). Among other applications, BPS is registered in the EU for use in formulations for “industrial manufacture of paper” (EC, 2006), but current amounts in the European paper cycle are virtually unknown. Although concerns about the current and potential future substitution of BPA by BPS have been expressed (EC, 2016b), quantitative data on presence, partitioning and persistence of BPA and BPS in the paper material cycle is extremely limited (Pivnenko et al., 2016a; US EPA, 2014). Without clearly defined substitution strategy for BPA, increased use of potentially harmful alternatives can be expected. The question is, to what extent will the European ban ensure BPA-free paper flows, and how might levels of BPS develop over time? In view of limited data availability and restricted timeframe for BPA ban in the EU to enter into force, comprehensive literature overview and systematic modeling can offer useful insights for decision-making.

The aim of this study is to provide an evaluation of the available literature on presence of BPA and BPS in thermal paper and to investigate the effects of phasing-out BPA and phasing-in BPS, as its partial replacement, within the European paper cycle. The intention is to quantify and demonstrate systematically the consequences of recent BPA-related European legislation and the potentials for achieving a clean material cycle. The specific objectives are to: i) Provide a comprehensive overview and evaluation of available data on the presence of BPA and BPS in thermal paper; ii) Establish a 
dynamic model for BPA and BPS based on a state-of-the-art material flow model of the European paper cycle (Pivnenko et al., 2016a); and iii) Based on proposed European legislation, define scenarios for phasing-out BPA and determining potential consequences for BPA and BPS flows in the European paper cycle. The work illustrates the principles for estimating temporal changes associated with chemical substitution within material recycling loops-principles that could be applied to other cases where the presence of chemicals (e.g. conventional use, restrictions on use or introduction of new chemicals) in materials is of potential concern.

\section{Materials and Methods}

\subsection{Literature overview and evaluation}

The existing literature concerning BPA and BPS in thermal paper receipts was reviewed from a global perspective. Scientific publications, public reports, patents, and ongoing projects were identified and evaluated. In total 29 experimental studies were identified, covering the period between 2009 and 2017. In case actual year of thermal paper sampling was not mentioned in a study, the publication year was used. The presence of either BPA or BPS in thermal paper may result from direct application of additives (e.g. developer in paper coating) or as contamination (e.g. through formulation impurities, paper recycling (up to $0.5 \mathrm{mg} / \mathrm{g}$ ) or direct contact with bisphenol-rich thermal paper (up to $0.1 \mathrm{mg} / \mathrm{g})$ ) (Konkel, 2013; Liao and Kannan, 2011b; Pivnenko et al., 2015a, 2015b). However, an unbiased threshold for distinguishing between amounts of BPA or BPS added directly or via contamination has not been identified. Hence, all reported concentrations above the respective limits of detection (LODs) were accounted for in this work. Values below respective LODs were excluded from statistical analyses for simplicity and transparency, as common substitution methods may have limited applicability at high degrees of censoring (Antweiler, 2015, 2008).

\subsection{Material and substance flow modeling}

Flows of BPA and BPS in the European paper cycle were modeled, following the state-of-the-art model with a step-wise modeling approach (Pivnenko et al., 2016a). In brief, the stepwise model was based on a combination of static and dynamic material and substance flow analysis. Static paper flow analysis was carried out in a previous study (Pivnenko et al., 2016a) to quantify paper flows in Europe in 2012. Although there is some decrease in the European paper consumption between 2007 and 2009, consumption remained rather steady in the period 2012-2016 (CEPI, 2016). Hence, the earlier study concerning year 2012 can be considered representative of the current flows of paper in the European paper cycle. On the other hand, static substance flow analysis was expanded with new and detailed 
data concerning BPA and BPS amounts in end-of-life (EOL) paper fractions and thermal paper (Tables 1-4). In addition, the present work is aiming to reflect on the terms of recent European legislation proposing a ban of BPA use in thermal paper and focus explicitly on the modeling of BPA phase-out and BPS phase-in within the European paper cycle. The substance flow model is primarily based on chemical concentrations in the EOL paper and paper products as model input and output parameters, respectively. Figure A1 (Appendix A) provides detailed overview of the inputs and outputs from each of the modeling steps. Definitions, key assumptions (further addressed in Section 2.5) and data sources for EOL paper fractions are outlined in Table 1 and final concentrations of BPA and BPS in discarded paper are presented in Table 2.

\subsection{Scenario analysis}

In paper products, BPA is primarily used as a developer in thermal paper production, but also as a plasticizer and plasticizer precursor for ink and glue formulations for paper conversion (Pivnenko et al., 2016a). A probable reduction in BPA use could lead to increased use of BPS and other alternatives, either in thermal paper only or in other paper products as well. Since BPS is potentially used as a partial substitute of BPA, the evaluation of BPS flows requires better understanding of BPA flows in the context of the newly proposed European legislation (i.e. scope, timeframe and maximum concentrations). In addition, reduction of a chemical's use is assumed to gradually take place within a phase-out period, i.e. period between a ban is proposed and the ban is fully implemented. To quantitatively reflect on these differences and potential developments, four alternative scenarios were assessed in the present work. While Scenario 1 and 2 addressed future dynamics of BPA flows, Scenario 3 and 4 addressed flows of BPS in reflection on the first two scenarios. The four scenarios were defined as follows:

i) In Scenario 1, BPA concentrations in thermal paper were assumed to reduce linearly within three years (between 2017 and 2020) down to $200 \mu \mathrm{g} / \mathrm{g}$ as defined by EC2016/2235 (EC, 2016a);

ii) In Scenario 2, in addition to BPA reduction in thermal paper (as defined in Scenario 1), other uses of BPA in paper production and conversion (ink constitute, glue formulation, etc.) were assumed to be phased out within three years, following BPA classification as SVHC (ECHA, 2017); 
iii) In Scenario 3, amounts of BPA reduced through implementation of Scenario 1 were assumed to be substituted by 50\% (w/w) of BPS, reflecting results of a recent study on use of BPA and its alternatives in Europe (Björnsdotter et al., 2017);

iv) In Scenario 4, in addition to BPS used for BPA substitution in thermal paper production (as defined in Scenario 3), BPS was further assumed to substitute 50\% (w/w) of BPA used in other potential applications within the paper industry (e.g. in adhesive formulations). BPS shares many similarities with BPA, e.g. a monomer used widely in epoxy resins, cyclic carbonates, dyestuff, flame-retardants, and fiber improvers (Molina-Molina et al., 2013).

A business-as-usual scenario, where amounts of BPA and BPS reflect the modeling year 2012 and remain unchanged (i.e. steady state), was used as a reference for comparison. 
Table 1. Paper product categories used in the present study with examples of paper products reported in the respective literature sources. Final concentrations for BPA and BPS in the seven EOL paper categories are provided in Table 2.

\begin{tabular}{|c|c|c|c|c|c|}
\hline \# & Present study & $\begin{array}{l}\text { Pivnenko et al., 2016b; Pivnenko et al., } \\
\text { 2015b }\end{array}$ & Gehring et al., 2004 & $\begin{array}{l}\text { Liao et al., 2012; Liao and } \\
\text { Kannan, 2011a }\end{array}$ & Fan et al., 2015 \\
\hline 1 & Carton board & $\begin{array}{l}\text { - Folding boxes - shipping } \\
\text { - Folding boxes - sales (Food packaging) } \\
\text { - Folding boxes - sales (Non-food } \\
\text { packaging) }\end{array}$ & & - Food cartons & \\
\hline 2 & Case materials & $\begin{array}{l}\text { - Corrugated boxes - shipping } \\
\text { - Corrugated boxes - sales (Food } \\
\text { packaging) } \\
\text { - Corrugated boxes - sales (Non-food } \\
\text { packaging) }\end{array}$ & - Corrugated board & & \\
\hline 3 & $\begin{array}{l}\text { Household \& } \\
\text { sanitary }\end{array}$ & - Tissue paper & - Toilet paper & $\begin{array}{l}\text { - Napkins } \\
\text { - Kitchen rolls } \\
\text { - Toilet paper }\end{array}$ & \\
\hline 4 & Newsprint & - Newspapers & - Newspapers & - Newspapers & - Newspaper \\
\hline 5 & $\begin{array}{l}\text { Other graphic } \\
\text { paper }\end{array}$ & $\begin{array}{l}\text { - Advertisements (non-glued) } \\
\text { - Advertisements (glued) } \\
\text { - Newsprint advertisements (non-glued) } \\
\text { - Newsprint advertisements (glued) } \\
\text { - Magazines/Journals/TV guides (non- } \\
\text { glued) } \\
\text { - Magazines/Journals/TV guides (glued) } \\
\text { - Office/administrative paper }\end{array}$ & $\begin{array}{l}\text { - Advertising supplements } \\
\text { - Free advertising papers } \\
\text { - Magazines } \\
\text { - Catalogues }\end{array}$ & $\begin{array}{l}\text { - Flyers } \\
\text { - Magazines } \\
\text { - Printing paper }\end{array}$ & $\begin{array}{l}\text { - Advertising paper } \\
\text { - Magazine paper } \\
\text { - Art paper }\end{array}$ \\
\hline 6 & Other paper & $\begin{array}{l}\text { - Envelopes } \\
\text { - Receipts } \\
\text { - Self Adhesives } \\
\text { - Books/booklets } \\
\text { - Phonebooks } \\
\text { - Other paper } \\
\text { - Paper plates/Cups } \\
\text { - Composites } \\
\text { - Labels/Cards } \\
\text { - Other cardboard }\end{array}$ & - Chromo board & $\begin{array}{l}\text { - Mailing envelopes } \\
\text { - Airplane luggage tags } \\
\text { - Tickets } \\
\text { - Airplane boarding } \\
\text { passes } \\
\text { - Food contact papers } \\
\text { - Business cards }\end{array}$ & $\begin{array}{l}\text { - Book paper } \\
\text { - Auto copy paper }\end{array}$ \\
\hline 7 & $\begin{array}{l}\text { Wrappings \& } \\
\text { packaging }\end{array}$ & $\begin{array}{l}\text { - Wrapping paper } \\
\text { - Kraft paper (brown/bleached) } \\
\text { - Egg trays \& alike } \\
\text { - Tubes } \\
\text { - Aseptic cartons }\end{array}$ & & & $\begin{array}{l}\text { - Packing paper } \\
\text { - Food wrapping paper }\end{array}$ \\
\hline
\end{tabular}


Table 2. Chemical concentrations in paper products contained in discarded paper (mg/kg for BPA and $\mu \mathrm{g} / \mathrm{kg}$ for BPS, dry matter), as well as the respective sources used in the calculations of the final concentrations.

\begin{tabular}{|c|c|c|c|c|}
\hline \multirow[t]{2}{*}{ Paper product category } & \multicolumn{2}{|c|}{ BPA (mg/kg) ${ }^{1}$} & \multicolumn{2}{|c|}{ BPS $(\mu \mathrm{g} / \mathrm{kg})^{2, \mathrm{a}}$} \\
\hline & SS & $\mathbf{R}$ & SS & $\mathbf{R}$ \\
\hline Carton board (CB) & 14 & 11 & 300 & 240 \\
\hline Case materials (CM) & 14 & 23 & 850 & 3100 \\
\hline Household \& sanitary (H\&S) & 15 & 19 & 100 & 100 \\
\hline Newsprint (NP) & 3 & 5 & 100 & 100 \\
\hline Other graphic paper (OG) & 8 & 45 & 100 & 300 \\
\hline Other paper (OP) & $42^{b}$ & $370^{\mathrm{b}}$ & $6000^{\mathrm{b}}$ & $58,000^{b}$ \\
\hline Wrappings \& packaging (WP) & 34 & 28 & 100 & 100 \\
\hline
\end{tabular}

\subsection{Data sources}

While data on European paper flows were based primarily on industry statistics for the year 2012 (see Pivnenko et al., 2016a for details), concentrations of BPA and BPS in non-thermal paper products were derived from the literature (Fan et al., 2015; Gehring et al., 2004; Liao et al., 2012; Liao and Kannan, 2011a; Pivnenko et al., 2016b; Pivnenko et al., 2015b). Table 1 provides the seven paper and board product categories defined and used in the present study, as well the examples of paper products sampled and reported in the literature. Model input concentrations of BPA and BPS in thermal paper derived from an evaluation of the available experimental literature (see Section 3.1 for details). Quantitative data sources reported in Tables 1, 3 and 4 were used in calculations of the final concentrations of BPA and BPS in each of the seven EOL paper product categories and provided in Table 2. The process transfer coefficients for BPA were obtained from Pivnenko et al. (2016a) while transfer coefficients for BPS were calculated and are provided in Appendix B (Table B1-B6). EOL paper for recycling was classified into four paper grades: grade A (mixed grades), grade B (corrugated and Kraft), grade $\mathrm{C}$ (newspapers and magazines), and grade $\mathrm{D}$ (high grades), following the classification commonly used to report the European EOL paper statistics (CEPI, 2016). Since there is no information available on the removal efficiency of BPS in re-processing paper for recycling, $40 \%$ was assumed for paper grades A, B, and D, corresponding to approximately four times higher water solubility of BPS in comparison to BPA (Pivnenko et al., 2015b). This is a simplification, as the specific physical and chemical conditions of paper recycling processes will influence the final partitioning of BPS between water and paper fibers, and hence affect removal efficiency. Due to the affinity of BPS to both water and paper fibers, accurate prediction of BPS partitioning in paper 
recycling processes has been characterized previously as challenging (Pivnenko et al., 2015b). For paper grade C, removal efficiency was assumed to be identical to BPA (i.e. 95\%) ( Pivnenko et al., 2016a).

\subsection{Model limitations}

While loss of paper fiber due to deterioration, as well as the removal of BPA and BPS in paper reprocessing were included in the model, other losses of chemicals in the paper cycle (e.g. migration, evaporation) were not explicitly included, due to a lack of consistent data. However, such losses are expected to be insignificant in comparison to the flows remaining in the paper cycle. In addition, some literature sources suggested that BPS can be more effective than BPA as a developer in thermal paper (Miljøstyrelsen, 2011), while other sources posit the opposite applies (Konkel, 2013). Patents related to manufacturing thermal paper list developers (including BPA and BPS) and specify that they can be used interchangeably, in the same amounts (Ikeda et al., 1996). Hence, the functional substitution coefficient of BPA by BPS (i.e. amounts of BPS used to replace given amounts of BPA in specific applications) was assumed to be 1 in this work. Market substitution of BPA by BPS was assumed to reflect the current extent of BPS use suggested by Björnsdotter et al. (2017) and based on thermal paper samples from the Netherlands, Spain, Sweden and Norway. Predicting market infiltration of BPS as BPA substitute can be challenging and was beyond the scope of the present study, while sensitivity of the model to market substitution and other prominent parameters was evaluated. Model sensitivity was assessed using a one-at-a-time approach for selected input parameters: functional and market substitution coefficients, BPS removal efficiency in paper reprocessing, and BPS concentrations in each of the seven discarded paper product categories. Model sensitivity was assessed on basis of sensitivity ratio as calculated by Equation 1 (Clavreul et al., 2012), below:

$$
S R=\frac{\frac{(\text { Result } 2-\text { Result } 1)}{\text { Result } 1}}{\frac{(\text { Parameter } 2-\text { Parameter } 1)}{\text { Parameter } 1}}
$$

Where, Parameter1 is the default input parameter value used in the model (e.g. substitution coefficients); Parameter2 is the default parameter value adjusted by $\pm 25 \%$; Result1 is the model result when default parameter value is used as model input; and Result2 is the model result when default parameter value either decreased (-25\%) or increased (+25\%) is used as model input. Scenario 3, as defined in the Section 2.3, was used as default. Hence, the adjustments in the input parameter values, as described above for model sensitivity assessment, were also applied in the 
context of Scenario 3. Total BPS amounts in paper products within the European paper cycle in the end of the modeling period were the model result of interest for the sensitivity analysis. For example, if a parameter has a sensitivity ratio of 2 , increase of its input value by $25 \%$ would result in $50 \%$ increase of the model result.

\section{Results and Discussion}

\subsection{Evaluation of the literature data}

Figure 1 provides an overview of quantitative data on the presence of BPA and BPS in thermal paper. Detailed data for each of the reviewed studies are presented in Table 3 and 4. Most of the studies concern thermal paper receipts in Europe or America (predominantly USA), while some also address receipts in Asia (China, Japan, South Korea, and Vietnam). The data suggest that BPA and BPS concentrations are higher in America than in Europe. The median concentrations of BPA (BPS) were found as $15.5 \mathrm{mg} / \mathrm{g}$ (11.5 mg/g) in America and $11.0 \mathrm{mg} / \mathrm{g}$ (6.2 mg/g) in Europe. In specific cases, concentrations as high as $43 \mathrm{mg} / \mathrm{g}$ (LA, USA) and $30 \mathrm{mg} / \mathrm{g}$ (MO, USA) were identified for BPA and BPS, respectively. While median BPA concentrations for samples derived from Asia are comparable to those from Europe, BPS concentrations data for the region is limited. Liao et al. (2012) reported BPS concentrations in 20 samples from Japan $(n=6)$, South Korea $(n=11)$, and Vietnam $(n=3)$. Considerable BPS concentrations in samples from Japan, were consistent with negligible concentrations of BPA and suggested use of BPS as BPA substitute following the ban on paper applications of BPA in Japan in 2001 (Liao et al., 2012; Liao and Kannan, 2011a).

Across all data, the overall median concentrations were 11.7 and $6.8 \mathrm{mg} / \mathrm{g}$ for BPA and BPS, respectively. In addition, the available data suggest that 93\% of thermal paper receipts contained BPA above respective detection limits, while 54\% contained BPS (Table 3 and 4). These values correspond with earlier studies suggesting that $70-80 \%$ of thermal paper in the EU contains BPA as the main developer (Miljøstyrelsen, 2011). Most of the samples contained one chemical (e.g. BPA or BPS) in relatively high concentrations, and the other one was detected at very low concentrations or not detected at all. Although the use of mixtures is technically feasible (Ikeda et al., 1996), the presence of more than one developer in relatively high concentrations in a single sample was not common and has only been documented for a few samples in two studies (Björnsdotter et al., 2017; Thayer et al., 2015). 


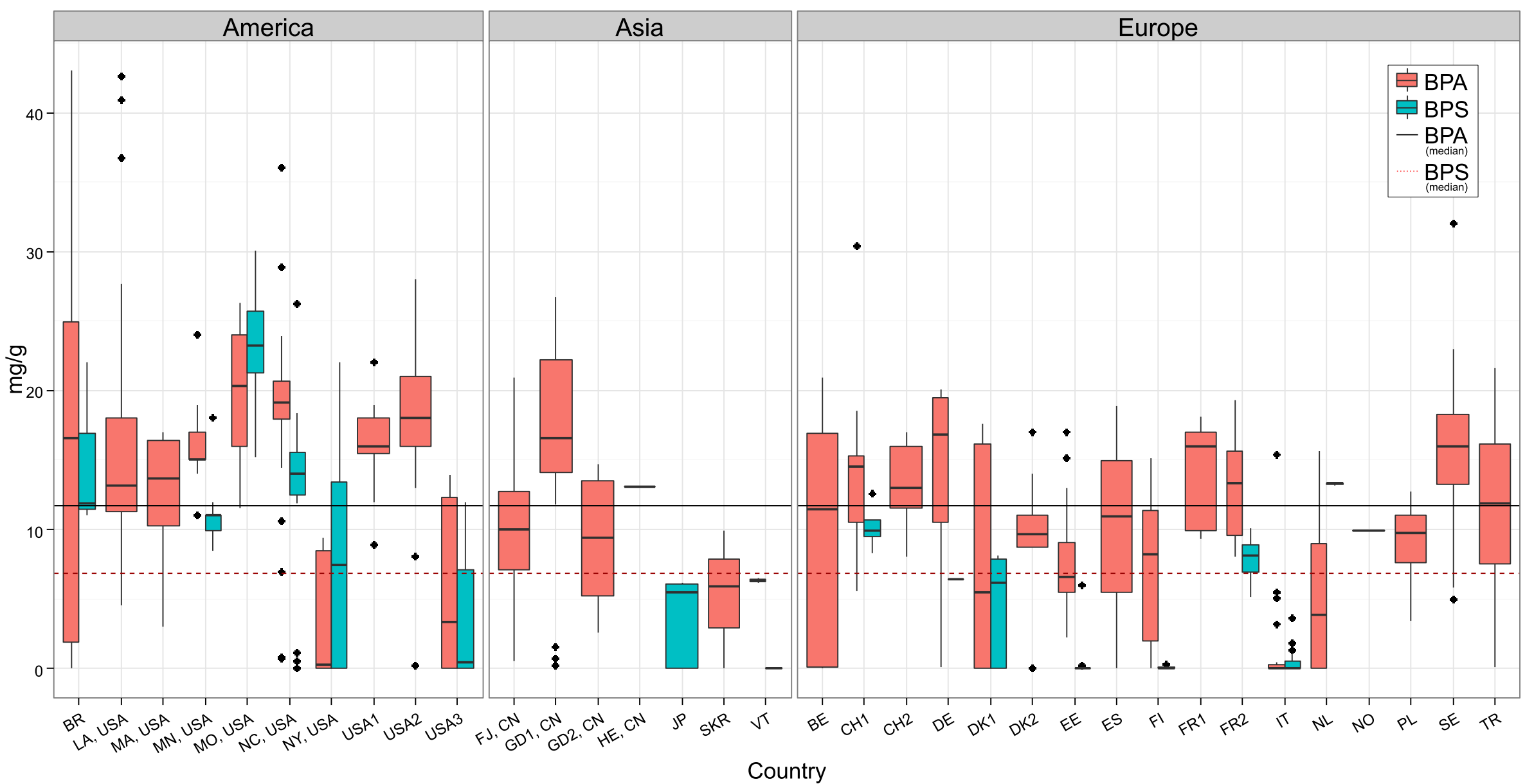

Figure 1. Overview of literature data providing concentrations of bisphenol A (BPA) and bisphenol S (BPS) in thermal paper receipts (mg/g). Boxplots contain 50\% of values and median values; whiskers range from min to $\max$ (or $5^{\text {th }}$ to $95^{\text {th }}$ percentile and outliers for larger datasets). Details of the presented data and literature sources are provided in Table 2 and 3. 
Table 3. Overview of literature data on presence of bisphenol A (BPA) in thermal paper receipts on the global market. *Limit of detection (LOD).

\begin{tabular}{|c|c|c|c|c|c|c|c|c|c|c|c|c|}
\hline$\#$ & Acronym & Origin & $\begin{array}{c}\text { Sample } \\
\text { collection } \\
\text { year }\end{array}$ & $\begin{array}{c}\text { Number of } \\
\text { samples } \\
\text { analysed }\end{array}$ & $\begin{array}{c}\text { LOD } \\
{[\mathrm{mg} / \mathrm{g}]}\end{array}$ & $\begin{array}{c}\text { 5th } \\
\text { percentile } \\
{[\mathrm{mg} / \mathrm{kg}]}\end{array}$ & $\begin{array}{l}\text { Median } \\
{[\mathrm{mg} / \mathrm{kg}]}\end{array}$ & $\begin{array}{c}\text { 95th } \\
\text { percentile } \\
\text { [mg/kg] }\end{array}$ & $\begin{array}{c}\text { Min } \\
{[\mathrm{mg} / \mathrm{kg}]}\end{array}$ & $\begin{array}{c}\text { Max } \\
{[\mathrm{mg} / \mathrm{kg}]}\end{array}$ & $\begin{array}{l}\text { Detection } \\
\text { ratio }\end{array}$ & Reference \\
\hline \multicolumn{13}{|c|}{ America } \\
\hline 1 & $\mathrm{BR}$ & Brazil & 2014 & 190 & $3 \mathrm{E}-04$ & 1.9 & 16.6 & 24.9 & 3E-04* & 43.0 & $92 \%$ & (Rocha et al., 2015) \\
\hline 2 & LA, USA & Louisiana, USA & $2010-2012$ & 170 & - & 8.3 & 13.2 & 27.7 & 4.5 & 42.6 & $99 \%$ & (Babu et al., 2015) \\
\hline 3 & MA, USA & Massachusetts, USA & 2011 & 10 & 0.9 & 4.9 & 13.7 & 16.9 & 3.0 & 17.0 & $80 \%$ & (Mendum et al., 2011) \\
\hline 4 & MN, USA & Minnesota, USA & 2013 & 19 & 0.2 & 12.2 & 15.0 & 22.0 & 11.0 & 24.0 & $47 \%$ & (MPCA, 2014) \\
\hline 5 & MO, USA & Missouri, USA & 2014 & 50 & - & 11.8 & 20.3 & 26.2 & 11.5 & 26.3 & $44 \%$ & (Hormann et al., 2014) \\
\hline 6 & NC, USA & $\begin{array}{l}\text { North Carolina, } \\
\text { USA }\end{array}$ & 2011-2013 & 77 & 0.2 & 5.1 & 19.2 & 25.4 & 0.7 & 36.0 & $45 \%$ & (Thayer et al., 2015) \\
\hline 7 & NY, USA & New York, USA & 2010 & 73 & 3E-07 & $7 \mathrm{E}-03$ & 0.3 & 8.5 & 5E-03 & 9.4 & $100 \%$ & $\begin{array}{c}\text { (Liao and Kannan, } \\
\text { 2011a) }\end{array}$ \\
\hline 8 & USA1 & Several states, USA & 2010 & 22 & $5 \mathrm{E}-02$ & 10.5 & 16.0 & 20.5 & 8.9 & 22.0 & $50 \%$ & (Schreder, 2010) \\
\hline 9 & USA2 & Several states, USA & 2010 & 36 & $2 \mathrm{E}-02$ & 6.4 & 18.0 & 27.2 & 0.2 & 28.0 & $47 \%$ & (Lunder et al., 2010) \\
\hline 10 & USA3 & Several states, USA & 2010 & 10 & 3E-07 & $1 \mathrm{E}-02$ & 3.3 & 12.3 & 1E-02 & 13.9 & $100 \%$ & $\begin{array}{c}\text { (Liao and Kannan, } \\
\text { 2011a) }\end{array}$ \\
\hline \multicolumn{13}{|c|}{ Asia } \\
\hline 11 & FJ, CN & Fujian, China & 2013 & 7 & $1 \mathrm{E}-02$ & 2.1 & 10.0 & 18.5 & 0.5 & 20.9 & $100 \%$ & (Gao et al., 2013) \\
\hline 12 & GD1, CN & Guangdong, China & 2013 & 54 & $1 \mathrm{E}-04$ & 1.3 & 16.6 & 25.0 & 0.2 & 26.8 & $100 \%$ & (Fan et al., 2015) \\
\hline 13 & GD2, CN & Guangdong, China & 2011 & 42 & 0.1 & 5.2 & 9.4 & 13.5 & 2.6 & 14.7 & $100 \%$ & (Lu et al., 2013) \\
\hline 14 & $\mathrm{HE}, \mathrm{CN}$ & Hebei, China & 2013 & 1 & - & - & 13.1 & - & 13.06 & 13.1 & $100 \%$ & (Liu et al., 2013) \\
\hline 15 & $\mathrm{JP}$ & Japan & 2010 & 6 & 3E-07 & 7E-07 & 7E-07 & 7E-07 & 7E-07 & 7E-07 & $0 \%$ & $\begin{array}{l}\text { (Liao and Kannan, } \\
\text { 2011a) }\end{array}$ \\
\hline 16 & SKR & South Korea & 2010 & 11 & 3E-07 & $2 \mathrm{E}-02$ & 5.9 & 9.8 & 2E-02 & 9.9 & $100 \%$ & $\begin{array}{l}\text { (Liao and Kannan, } \\
\text { 2011a) }\end{array}$ \\
\hline 17 & VT & Vietnam & 2010 & 3 & 3E-07 & 6.2 & 6.3 & 6.5 & 6.2 & 6.5 & $100 \%$ & $\begin{array}{c}\text { (Liao and Kannan, } \\
\text { 2011a) }\end{array}$ \\
\hline \multicolumn{13}{|c|}{ Europe } \\
\hline 18 & $\mathrm{BE}$ & Belgium & 2011 & 44 & $1 \mathrm{E}-05$ & $2 \mathrm{E}-04$ & 11.5 & 20.2 & 1E-05 & 20.9 & $100 \%$ & (Geens et al., 2012) \\
\hline 19 & CH1 & Switzerland & 2013-2014 & 124 & 1.2 & 8.1 & 14.5 & 17.2 & 5.6 & 30.4 & $81 \%$ & (Goldinger et al., 2015) \\
\hline 20 & $\mathrm{CH} 2$ & Switzerland & 2010 & 13 & 5E-04 & 9.5 & 13.0 & 17.0 & 8.0 & 17.0 & $85 \%$ & $\begin{array}{l}\text { (Biedermann et al., } \\
\text { 2010) }\end{array}$ \\
\hline 21 & $\mathrm{DE}$ & Germany & 2014 & 14 & 7E-04 & 1.0 & 16.8 & 20.0 & 0.1 & 20.1 & $93 \%$ & (Zech, 2015) \\
\hline 22 & DK1 & Denmark & 2014 & 13 & $2 \mathrm{E}-03$ & $6 \mathrm{E}-03$ & 5.5 & 17.3 & 3E-03 & 17.6 & $92 \%$ & $\begin{array}{l}\text { (Pivnenko et al., } \\
\text { 2015b) }\end{array}$ \\
\hline 23 & DK2 & Denmark & 2010 & 13 & $1 \mathrm{E}-04$ & $2 \mathrm{E}-02$ & 9.7 & 15.8 & $1 \mathrm{E}-03$ & 17.0 & $69 \%$ & (Miljøstyrelsen, 2011) \\
\hline 24 & $\mathrm{EE}$ & Estonia & 2009-2015 & 60 & 0.2 & 2.4 & 6.6 & 12.7 & 2.2 & 17.0 & $75 \%$ & (Püssa, 2016) \\
\hline
\end{tabular}




\begin{tabular}{|c|c|c|c|c|c|c|c|c|c|c|c|c|}
\hline 25 & ES & Spain & 2017 & 3 & 5E-03 & 1.1 & 11.0 & 18.1 & 2E-02 & 18.9 & $100 \%$ & $\begin{array}{c}\text { (Björnsdotter et al., } \\
\text { 2017) }\end{array}$ \\
\hline 26 & FI & Finland & 2013 & 10 & $1 \mathrm{E}-02$ & 5E-02 & 8.3 & 14.4 & 5E-02 & 15.1 & $60 \%$ & $\begin{array}{l}\text { (Rajasärkkä et al., } \\
\text { 2014) }\end{array}$ \\
\hline 27 & FR1 & France & 2013-2014 & 10 & 0.3 & 9.4 & 16.0 & 17.9 & 9.3 & 18.1 & $90 \%$ & (Ndaw et al., 2016) \\
\hline 28 & FR2 & France & 2011 & 50 & 0.1 & 8.6 & 13.4 & 17.9 & 8.0 & 19.3 & $72 \%$ & (ANSES, 2013) \\
\hline 29 & IT & Italy & 2015-2016 & 50 & $1 \mathrm{E}-06$ & $5 \mathrm{E}-04$ & 8E-03 & 5.3 & $3 \mathrm{E}-04$ & 15.3 & $56 \%$ & (Russo et al., 2017) \\
\hline 30 & NL & Netherlands & 2017 & 6 & $5 \mathrm{E}-03$ & $1 \mathrm{E}-02$ & 3.8 & 14.1 & $1 \mathrm{E}-02$ & 15.7 & $100 \%$ & $\begin{array}{c}\text { (Björnsdotter et al., } \\
\text { 2017) }\end{array}$ \\
\hline 31 & NO & Norway & 2017 & 1 & $5 \mathrm{E}-03$ & - & 9.9 & - & 9.9 & 9.9 & $100 \%$ & $\begin{array}{c}\text { (Björnsdotter et al., } \\
\text { 2017) }\end{array}$ \\
\hline 32 & PL & Poland & 2017 & 4 & - & 4.3 & 9.8 & 12.4 & 3.4 & 12.8 & $100 \%$ & $\begin{array}{l}\text { (Lawrywianiec et al., } \\
\text { 2017) }\end{array}$ \\
\hline 33 & SE & Sweden & 2010 & 16 & - & 5.6 & 16.0 & 25.3 & 5.0 & 32.0 & $100 \%$ & $\begin{array}{c}\text { (Östberg and } \\
\text { Noaksson, 2010) }\end{array}$ \\
\hline 34 & TR & Turkey & 2016 & 12 & $1 \mathrm{E}-02$ & 0.3 & 11.9 & 20.8 & 0.1 & 21.7 & $100 \%$ & (Yalcin et al., 2016) \\
\hline \multicolumn{2}{|c|}{ Total } & & & 1224 & & & 11.7 & & & & $93 \%$ & \\
\hline
\end{tabular}


Table 4. Overview of literature data on presence of bisphenol S (BPS) in thermal paper receipts on the global market.

\begin{tabular}{|c|c|c|c|c|c|c|c|c|c|c|c|c|}
\hline$\#$ & Acronym & Origin & $\begin{array}{c}\text { Sample } \\
\text { collection } \\
\text { year }\end{array}$ & $\begin{array}{c}\text { Number of } \\
\text { samples } \\
\text { analysed }\end{array}$ & $\begin{array}{c}\text { LOD } \\
\text { [mg/g] }\end{array}$ & $\begin{array}{c}\text { 5th } \\
\text { percentile } \\
\text { [mg/kg] }\end{array}$ & $\begin{array}{l}\text { Median } \\
\text { [mg/kg] }\end{array}$ & $\begin{array}{c}\text { 95th } \\
\text { percentile } \\
\text { [mg/kg] }\end{array}$ & $\begin{array}{c}\text { Min } \\
{[\mathrm{mg} / \mathrm{kg}]}\end{array}$ & $\begin{array}{c}\text { Max } \\
{[\mathrm{mg} / \mathrm{kg}]}\end{array}$ & $\begin{array}{l}\text { Detection } \\
\text { ratio }\end{array}$ & Reference \\
\hline \multicolumn{13}{|c|}{ America } \\
\hline 1 & $\mathrm{BR}$ & Brazil & 2014 & 190 & 3E-05 & - & 11.9 & - & 11.0 & 22.0 & $6 \%$ & $\begin{array}{c}\text { (Rocha et al., } \\
\text { 2015) }\end{array}$ \\
\hline 2 & MN, USA & Minnesota, USA & 2013 & 19 & 0.1 & 9.1 & 11.0 & 15.6 & 8.5 & 18.0 & $47 \%$ & $\begin{array}{c}\text { (MPCA, } \\
\text { 2014) }\end{array}$ \\
\hline 3 & MO, USA & Missouri, USA & 2014 & 50 & - & 19.4 & 23.2 & 28.7 & 15.2 & 30.1 & $52 \%$ & $\begin{array}{l}\text { (Hormann et } \\
\text { al., 2014) }\end{array}$ \\
\hline 4 & NC, USA & North Carolina, USA & 2011-2013 & 77 & 2E-02 & 3E-02 & 14.0 & 18.3 & 3E-02 & 26.2 & $52 \%$ & $\begin{array}{l}\text { (Thayer et } \\
\text { al., 2015) }\end{array}$ \\
\hline 5 & NY, USA & New York, USA & 2010 & 81 & 3E-08 & $3 \mathrm{E}-04$ & 7.4 & 13.4 & $1 \mathrm{E}-05$ & 22.0 & $100 \%$ & $\begin{array}{c}\text { (Liao et al., } \\
\text { 2012) }\end{array}$ \\
\hline 6 & USA3 & Several states, USA & 2010 & 10 & 3E-08 & $1 \mathrm{E}-02$ & 0.4 & 7.1 & $1 \mathrm{E}-03$ & 12.0 & $100 \%$ & $\begin{array}{c}\text { (Liao et al., } \\
\text { 2012) }\end{array}$ \\
\hline \multicolumn{13}{|c|}{ Asia } \\
\hline 7 & JP & Japan & 2010 & 6 & $3 \mathrm{E}-08$ & $2 \mathrm{E}-02$ & 5.5 & 6.1 & $5 \mathrm{E}-04$ & 6.1 & $100 \%$ & $\begin{array}{l}\text { (Liao et al., } \\
\text { 2012) }\end{array}$ \\
\hline 8 & SKR & South Korea & 2010 & 11 & 3E-08 & $1 \mathrm{E}-04$ & 8E-04 & 9E-03 & 9E-05 & $1 \mathrm{E}-02$ & $100 \%$ & $\begin{array}{l}\text { (Liao et al., } \\
\text { 2012) }\end{array}$ \\
\hline 9 & VT & Vietnam & 2010 & 3 & 3E-08 & $1 \mathrm{E}-04$ & 3E-04 & 5E-04 & $1 \mathrm{E}-04$ & $6 \mathrm{E}-04$ & $100 \%$ & $\begin{array}{c}\text { (Liao et al., } \\
\text { 2012) }\end{array}$ \\
\hline \multicolumn{13}{|c|}{ Europe } \\
\hline 10 & $\mathrm{CH} 1$ & Switzerland & $2013-2014$ & 124 & 2 & 8.5 & 10.0 & 12.2 & 8.3 & 12.6 & $3 \%$ & $\begin{array}{l}\text { (Goldinger } \\
\text { et al., 2015) }\end{array}$ \\
\hline 11 & DK1 & Denmark & 2014 & 13 & 7E-03 & 8E-03 & 6.2 & 8.1 & 8E-03 & 8.1 & $62 \%$ & $\begin{array}{l}\text { (Pivnenko et } \\
\text { al., 2015b) }\end{array}$ \\
\hline 12 & $\mathrm{EE}$ & Estonia & 2009-2015 & 60 & $1 \mathrm{E}-03$ & $2 \mathrm{E}-04$ & 3E-03 & 6.0 & $1 \mathrm{E}-04$ & 6.0 & $85 \%$ & $\begin{array}{l}\text { (Püssa, } \\
\text { 2016) }\end{array}$ \\
\hline 13 & FI & Finland & 2013 & 10 & $1 \mathrm{E}-04$ & 2E-03 & $1 \mathrm{E}-02$ & 0.2 & 9E-04 & 0.2 & $40 \%$ & $\begin{array}{l}\text { (Rajasärkkä } \\
\text { et al., 2014) }\end{array}$ \\
\hline 14 & FR2 & France & 2011 & 50 & $1 \mathrm{E}-03$ & 5.2 & 8.1 & 9.6 & 5.1 & 10.1 & $24 \%$ & $\begin{array}{l}\text { (Anses, } \\
\text { 2013) }\end{array}$ \\
\hline 15 & IT & Italy & 2015-2016 & 50 & $4 \mathrm{E}-05$ & $2 \mathrm{E}-02$ & 3E-02 & 1.6 & $1 \mathrm{E}-02$ & 3.6 & $56 \%$ & $\begin{array}{c}\text { (Russo et al., } \\
\text { 2017) }\end{array}$ \\
\hline 16 & NL & Netherlands & 2017 & 6 & 5E-02 & 13.2 & 13.3 & 13.4 & 13.1 & 13.4 & $33 \%$ & $\begin{array}{l}\text { (Björnsdotter } \\
\text { et al., 2017) }\end{array}$ \\
\hline Tot & & & & 760 & & & 6.8 & & & & $54 \%$ & \\
\hline
\end{tabular}


Systematic repeated measurements from specific producers of thermal paper or geographical areas were not available and rather than constructing complete time series, correlation of BPA and BPS amounts and year of sampling was explored. Temporal variations of the data (Figure C1) show a clearly declining trend in BPA median concentrations from the analysed studies. Liao et al. (2012) also showed a significant negative correlation between BPA and BPS in thermal paper analysed in their study, thereby indicating relatively high BPA concentrations in samples with low BPS concentrations, and vice versa. As Figure C1 suggests older studies (2010-2013) show an increase in median BPS concentrations, however, latest studies from Europe (2015-2017) (Björnsdotter et al., 2017; Russo et al., 2017) suggest rather limited use of BPS. Even though correlation of BPS amounts and sampling years showed larger uncertainties (expressed as 95\% confidence interval, see Figure C1 for details) compared to BPA, decreasing BPS amounts with time may illustrate increasing use of BPA alternatives other than BPS. For example, $15 \%$ of the sampled receipts from Denmark $(n=13)$ contained neither BPA nor BPS (Pivnenko et al., 2015b), and 16\% of Swiss samples ( $\mathrm{n}=124$ ) contained Pergafast ${ }^{\circledR}$ and D-8 as color developers (Goldinger et al., 2015). In fact, Björnsdotter et al. (2017) suggested extensive use of Pergafast 201 and D-8 in thermal paper samples from the Netherlands, Norway, and Sweden. Results presented by the authors suggest that BPS may currently represent approximately 50\% of BPA alternatives in European thermal paper receipts. This value (i.e. $50 \%$ ) was used as a market substitution coefficient in assessment of the Scenarios 3 and 4 in the present work. Overall, data on the presence of BPA alternatives other than BPS are extremely limited, and so drawing conclusions regarding the current or potential use of these alternatives in paper is challenging. Impact of the BPS market substitution coefficient on modeling results was assessed in the sensitivity analysis.

\subsection{Material and substance flow modeling}

Consumption of BPA for thermal paper production was estimated to be 1100 tonnes/year, which is higher than previously estimated (Pivnenko et al., 2016a) and resulted from inclusion of additional data sources for estimation of BPA concentrations in the discarded paper (see Figure C2 for details of BPA flows within the European paper cycle). However, these values are lower than previously estimated by the EU for 2006 (1890 tonnes/year) (JRC-IHCP, 2008), thus suggesting a potential reduction of BPA use in thermal paper on the European market. This was also supported by the literature data (see Figure C1 for details) and discussed in Section 3.1. For comparison, the estimated BPA amounts used in paper conversion are somewhat lower (500 tonnes/year) when compared to paper production. Among other, thermal paper receipts are part of the “other paper” product category, 
which primarily results in outstanding BPA and BPS concentrations (Table 2) and the largest flows of BPA and BPS in the European paper cycle (Figure C2 and C3). As Figure C3 suggests, approximately 200 tonnes/year of BPS are already used in paper in Europe, the vast majority of which is used in thermal paper production (180 tonnes), while about 10\% may be used in paper conversion (e.g. epoxy resin formulations) (Li et al., 1999). Estimates of BPS amounts in the European paper cycle have not been previously reported. The largest share of BPS is in the residual waste paper, which is collected as part of the mixed waste. In Europe mixed waste is primarily landfilled or incinerated, potentially leading to leaching and environmental release of BPS or its complete destruction, respectively (Morin et al., 2015). However, substantial amounts of BPS are contained in the EOL paper for recycling, which leads to presence of BPS in paper products incorporating recycled fibers. Due to limited data regarding the presence of BPS in paper products other than thermal paper receipts, the BPS amounts used in paper conversion are rather uncertain and should be verified in future research.

Figure 2 shows the modeled results of the BPA phase-out and its partial substitution by BPS, as defined in the Scenarios 1-4 (see Section 2.3 for details). The modeled BPA and BPS amounts in paper products in reference scenarios (2012) were approximately 2200 and 200 tonnes per year, respectively. While the amounts of BPA (and BPS) used in thermal paper production can be estimated from experimental data for concentrations in thermal paper products from the literature (Table 3 and 4), the amounts added in paper conversion (i.e. non-thermal paper applications) are rather uncertain. As previously mentioned, presence may result partly from the introduction of BPA and BPS in epoxy resins, fiber improvers, dyestuff, or as impurities. In addition, some of BPA and BPS in paper products can also result from pre-existing contamination of paper products following the recycling of thermal paper, because chemicals (including bisphenols) are not completely removed in paper reprocessing (BMELV, 2012; Schabel, 2011). Based on the available data, the "separation" of these two sources of BPA and BPS in the non-thermal paper product categories cannot be achieved. The colored areas in Figure 2, between the two curves for BPA and BPS, respectively, thereby represent the uncertainty of the average BPA and BPS amounts in the European paper cycle; the two curves for either BPA (Scenario 1 and 2) or BPS (Scenario 3 and 4) illustrate the expected boundaries. 


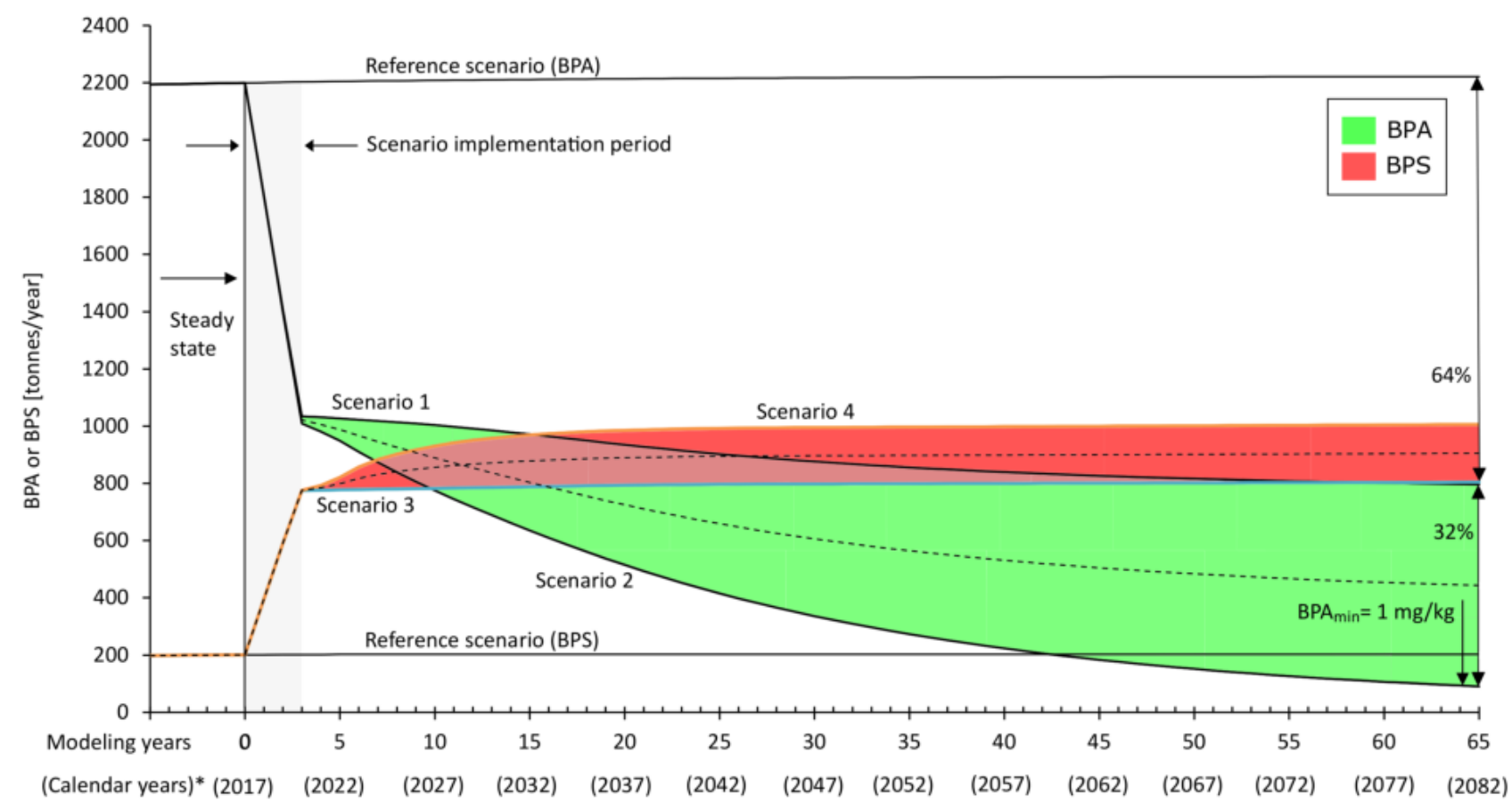

Figure 2. Modeled amounts (tonnes/year) of BPA and BPS in European paper products. Initial shaded area (years 0 to 3) represents the scenario implementation period. Dotted lines represent averages between Scenarios 1 and 2 (for BPA) and Scenarios 3 and 4 (for BPS). Colored areas between the two curves represent the range of BPA and BPS amounts in paper products following implementation of the scenarios. The lowest BPA concentration achieved within the modeled period was approximately $1 \mathrm{mg} / \mathrm{kg}$. *Calendar years are indicative and used for illustration purposes only; they may not reflect the actual situation in a given year.

After the implementation period of three years and a steep decline of BPA amounts in paper products (also illustrating that the vast majority of BPA in the current cycle comes from added amounts rather than BPA already accumulated), BPA phase-out is rather gradual, in particular in Scenario 2. Over a modeling period of 65 years, BPA amounts were reduced by 64\% in Scenario 1 and almost completely eliminated (96\%) in Scenario 2. Such a considerable difference between the scenario results points out the range of uncertainty in the future BPA amounts in paper products, depending on developments in BPA use. However, even when Scenario 2 was implemented, more than 60 years were needed to reach the lowest BPA concentrations (below $1 \mathrm{mg} / \mathrm{kg}$ ) in the paper products. These concentrations would still correspond to approximately 90 tonnes of BPA in the European paper products. BPA amounts were not expected to reach zero, since by definition of Scenario 2, some amounts of BPA (200 $\mu \mathrm{g} / \mathrm{g}$ of thermal paper) can still be added in paper production. Overall, this suggests that a "legacy period" (i.e. measurable concentrations after a ban) for BPA could be even longer than previously 
proposed (Pivnenko et al., 2016a). This also suggests that very long time periods may be needed to ensure "clean" flows of material cycles such as paper despite rather short phase-out periods of unwanted chemicals.

Assuming that BPS represents 50\% of BPA alternatives (as mentioned previously), a decrease in BPA amounts will result in increased BPS use and its gradual accumulation in the paper recycling loop, eventually converging towards a steady-state (Figure 2). A steady-state is achieved much faster by BPS than by BPA, primarily as the result of the higher removal efficiency of BPS in paper reprocessing compared to BPA (see Section 2.4 for details). In Scenario 3, the BPS amount will increase fourfold from the current 200 tonnes/year (i.e. the reference scenario corresponding to 2012) to approximately 800 tonnes/year. An even further increase (up to 1000 tonnes/year) will result in the case of Scenario 4, in which also BPA used in non-thermal paper applications was partially substituted by BPS. As shown in Figure 2, the steady-state amounts of BPS (approximately 1000 tonnes/year) appear to be considerably lower than the reference scenario for BPA (approximately 2200 tonnes/year). However, this does not take into account the use of BPA alternatives other than BPS, which requires additional data and research attention.

\subsection{Model sensitivity assessment}

The model results (i.e. total BPS amounts in paper products) depend on a variety of input parameters and their mathematical relationships within the model. These relationships include additions (e.g. BPS added to the cycle), subtractions (e.g. BPS removed from the cycle) and multiplications (e.g. transfer coefficients, substitution coefficients). In addition, recycling of paper and incomplete removal of BPS (or BPA) contributes to non-linear effects of parameter variation on the variation of the model results. Hence, sensitivity ratios (SRs) can be expected to be different from 1 . The resulting SRs indicate the direct relevance of changes in an input parameter value on the model result compared to the default result. Hence, the higher the SR, the more critical the parameter value choice for the model outcome. As illustrated by the data presented in Table 5, model sensitivity to input parameter variations showed SRs lower than 1 . This corresponds to a variation in the total BPS amounts in the European paper products less than $25 \%$ for $25 \%$ input parameter variation for the selected parameters. The functional and market substitution coefficients (i.e. amount of BPS used for BPA substitution) were the most important parameters influencing the modeling results, with SRs of 0.75 in both cases. In addition to BPS used in thermal paper production in Europe, BPS is added into the paper cycle in paper conversion and through import of paper products for use (see Figure C3 for details). Since the 
last two sources of BPS are not affected by a substitution coefficient, but influence BPS amounts in paper products through recycling, the respective SRs are lower than 1. Although the removal efficiency of a chemical in paper re-processing may significantly influence the content of the chemical in specific paper products, the influence of BPS removal efficiency on its total content in the European paper was rather limited (sensitivity ratio $\leq 0.1$ ). This points out the fact that while considerable amounts of BPS are re-introduced into the cycle through paper recycling, amounts of BPS added in paper production and manufacturing through BPA substitution are substantially higher. With respect to BPS concentrations in EOL paper, the larger BPS flow (a mathematical product of concentration and paper flow magnitude) was associated to an EOL paper category the larger influence BPS concentration variations in this category had on the total BPS amounts. "Other paper" (associated to approximately 100 tonnes of BPS in EOL paper (Figure C3)) showed the highest sensitivity ratio of 0.23 followed by “case materials” (associated to approximately 20 tonnes of BPS in EOL paper (Figure C3)) with a sensitivity ratio of 0.01 . Although sensitivity ratios lower than 1 sometimes are not regarded as critical (Heijungs and Kleijn, 2001), they should be interpreted with caution. Furthermore, interaction effects (variation of the result due to simultaneous variation of parameters) are not considered in the present sensitivity assessment (i.e. local sensitivity analysis). Although they have been shown to be of minor importance in typical dynamic MFA models, they may become relevant in models of (partly) closed material cycles (Džubur et al., 2016). In the present model, however, a local sensitivity approach was chosen to identify the most crucial input parameters out of a group of model parameters and not to explore the output variation across the full variation range of input parameters. Such an approach (i.e. global sensitivity analysis) could be chosen in a future study, when more reliable data becomes available to define probable parameter ranges for all input parameters. 
Table 5. Sensitivity analysis of prominent input parameters concerning BPS amounts in the model. Results illustrate the total amounts of BPS in paper products within the European paper cycle in the end of the modeling period (65 years).

\begin{tabular}{|c|c|c|c|c|c|c|c|c|c|}
\hline \multirow{2}{*}{ Parameter name } & \multirow{2}{*}{ Unit } & \multicolumn{3}{|c|}{ Input parameter value } & \multicolumn{3}{|c|}{ Model output [t/a] } & \multicolumn{2}{|c|}{$\begin{array}{c}\text { Sensitivity ratio } \\
\text { (SR) }\end{array}$} \\
\hline & & Parameter $1^{\mathrm{a}}$ & $\begin{array}{c}\text { Parameter } 2 \\
(-25 \%)\end{array}$ & $\begin{array}{c}\text { Parameter } 2 \\
(+25 \%)\end{array}$ & Result 1 & $\begin{array}{c}\text { Result } 2 \\
(-25 \%)\end{array}$ & $\begin{array}{r}\text { Result } 2 \\
(+25 \%)\end{array}$ & $(-25 \%)$ & $(+25 \%)$ \\
\hline Functional substitution coefficient* & - & 1 & 0.75 & 1.25 & 804.0 & 653.8 & 954.3 & 0.75 & 0.75 \\
\hline Market substitution coefficient (BPS)* & - & 0.5 & 0.375 & 0.625 & 804.0 & 653.8 & 954.3 & 0.75 & 0.75 \\
\hline Removal efficiency & $\%$ & 40 & 30 & 50 & 804.0 & 825.0 & 787.4 & 0.10 & $0.08^{\mathrm{b}}$ \\
\hline Carton board & $\mathrm{mg} / \mathrm{kg}$ & $300 / 240$ & $225 / 180$ & $375 / 300$ & 804.0 & 803.8 & 804.3 & 0.001 & 0.001 \\
\hline Case materials & $\mathrm{mg} / \mathrm{kg}$ & $850 / 3100$ & $638 / 2325$ & $1063 / 3875$ & 804.0 & 801.2 & 806.9 & 0.01 & 0.01 \\
\hline Household \& sanitary & mg/kg & $100 / 100$ & $75 / 75$ & $125 / 125$ & 804.0 & 803.6 & 804.4 & 0.002 & 0.002 \\
\hline Newsprint & $\mathrm{mg} / \mathrm{kg}$ & $100 / 100$ & $75 / 75$ & $125 / 125$ & 804.0 & 803.9 & 804.2 & 0.001 & 0.001 \\
\hline Other graphic paper & $\mathrm{mg} / \mathrm{kg}$ & $100 / 300$ & $75 / 225$ & $125 / 375$ & 804.0 & 803.6 & 804.5 & 0.002 & 0.002 \\
\hline Other paper & $\mathrm{mg} / \mathrm{kg}$ & $6000 / 58,000$ & $4500 / 43500$ & $7500 / 72500$ & 804.0 & 757.6 & 850.5 & 0.23 & 0.23 \\
\hline Wrapping \& packaging & $\mathrm{mg} / \mathrm{kg}$ & $100 / 100$ & $75 / 75$ & $125 / 125$ & 804.0 & 803.7 & 804.4 & 0.002 & 0.002 \\
\hline
\end{tabular}

${ }^{a}$ Concentrations for both source segregated and residual discarded paper are given for paper product categories; ${ }^{b}$ Removal efficiency for Grade $\mathrm{C}$ paper for recycling varied between $0.7125(-25 \%)$ and $1(+25 \%)$, resulting in asymmetric results.*Functional substitution coefficient represents the mass ratio of either BPS or BPA used in a developer formulation for thermal paper applications; Market substitution coefficient represents the mass ratio of BPS to all other BPA-alternatives used on the European market. 


\section{Conclusions}

The results of the literature data evaluation suggested extensive use of BPA in thermal paper on a global scale (identified in 93\% of samples) and the use of BPS as one of the principal substitutes for BPA in thermal paper applications (identified in 54\% of samples). For both BPA and BPS, median concentrations were higher in America when compared to Europe, while quantitative data from Asia were rather limited. Temporal analysis suggested reduced use of BPA throughout the years, as well as potential reduction of BPS use in the recent years. Potentially decreasing use of BPS can be attributed to use of BPA alternatives other than BPS (e.g. Pergafast ${ }^{\circledR}$ and D-8), data on which is scarce and additional research efforts are required. Nevertheless, data suggest substantial share of BPS (approximately 50\%) among potential BPA alternatives in European thermal paper. The modeling results quantitatively illustrated potential long-term effects of the currently proposed EU legislation, and unless further measures are taken, BPS accumulation and BPA contamination in paper products can be expected for several decades to come. Overall, this work illustrates on the example of BPA and BPS that ban on use of a chemical may not have the intended effects of ensuring clean material cycles, unless material decontamination and chemical substitution strategies are clearly formulated and implemented. Although this study addresses the specific case of the selected bisphenols (BPA and BPS) in paper products, the modeling approach can be applied to assess chemical flows (including the substitution of one chemical by another) in any product within circular material flows. Finally, this work demonstrates that the importance of chemical compounds in material cycles should not be neglected while our society is moving from linear production concepts towards circular economy solutions.

\section{Acknowledgements}

The authors would like to acknowledge the financial support of the Danish Research Council through the IRMAR project (grant no. 11-116775).

Appendices A, B and C are available online for free download. 


\section{References}

ANSES, 2013. Evaluation des risques du bisphénol A (BPA) pour la santé humaine. Tome 1. Agence Nationale de Sécurité Sanitaire del'Alimentation, de l'Environnement et du Travail (ANSES). French Agency for Food, Environmental and Occupational Health \& Safety, Paris, Fr.

Antweiler, R.C., 2015. Evaluation of Statistical Treatments of Left-Censored Environmental Data Using Coincident Uncensored Data Sets. II. Group Comparisons. Environ. Sci. Technol. 49, 13439-13446. doi:10.1021/acs.est.5b02385

Antweiler, R.C., 2008. Evaluation of Statistical Treatments of Left-Censored Environmental Data using Coincident Uncensored Data Sets: I. Summary Statistics. Environ. Sci. Technol. 42, 3732-3738. doi:10.1021/acs.est.5b02385

Babu, S., Uppu, S.N., Martin, B., Agu, O.A., Uppu, R.M., 2015. Unusually high levels of bisphenol A (BPA) in thermal paper cash register receipts (CRs): development and application of a robust LC-UV method to quantify BPA in CRs. Toxicol. Mech. Methods 1-7. doi:10.3109/15376516.2015.1045661

Biedermann, S., Tschudin, P., Grob, K., 2010. Transfer of bisphenol A from thermal printer paper to the skin. Anal. Bioanal. Chem. 398, 571-6.

Björnsdotter, M.K., Jonker, W., Legradi, J., Kool, J., Ballesteros-Gómez, A., 2017. Bisphenol A alternatives in thermal paper from the Netherlands, Spain, Sweden and Norway. Screening and potential toxicity. Sci. Total Environ. 601-602, 210-221. doi:10.1016/j.scitotenv.2017.05.171

BMELV, 2012. Ausmaß der Migration unerwünschter Stoffe aus Verpackungsmaterialien aus Altpapier in Lebensmitteln, BMELV (German Federal Ministry of Food, Agriculture and Consumer Protection). Bonn, Germany [WWW Document]. URL http://download.ble.de/09HS012.pdf (accessed 11.19.15).

CEPI, 2016. Annual Statistics 2016. European Pulp and Paper Industry. Confederation of European Paper Industries, Brussels.

CEPI, 2013. CEPI sustainability report 2013. European Paper Industry - Advancing the bioeconomy, Confederation of European Paper Industries (CEPI). Brussels, Belgium.

Chen, Y., Shu, L., Qiu, Z., Lee, D.Y., Settle, S.J., Que Hee, S., Telesca, D., Yang, X., Allard, P., 2016. Exposure to the BPA-Substitute Bisphenol S Causes Unique Alterations of Germline Function. PLoS Genet. 12, 1-22. doi:10.1371/journal.pgen.1006223

Clavreul, J., Guyonnet, D., Christensen, T.H., 2012. Quantifying uncertainty in LCA-modelling of waste management systems. Waste Manag. 32, 2482-2495.

doi:10.1016/j.wasman.2012.07.008

Džubur, N.., Buchner, H.., Laner, D.., 2016. Evaluating the Use of Global Sensitivity Analysis in Dynamic MFA. J. Ind. Ecol. 0. doi:10.1111/jiec.12497

EC, 2016a. COMMISSION REGULATION (EU) 2016/2235 of 12 December 2016 amending Annex XVII to Regulation (EC) No 1907/2006 of the European Parliament and of the Council concerning the Registration, Evaluation, Authorisation and Restriction of Chemicals (REACH) as regar, Official Journal of the European Union. doi:http://eurlex.europa.eu/pri/en/oj/dat/2003/1_285/1_28520031101en00330037.pdf 
EC, 2016b. Note for the attention of Mr G. Dancet, executive director ECHA. Request to the European Chemicals Agency (ECHA) from the European Commission (EC) 1-3.

EC, 2006. Regulation No 1907/2006 of the European Parliament and the Council of 18 December 2006 concerning the Registration, Evaluation, Authorisation and Restriction of Chemicals (REACH), establishing a European Chemicals Agency. Off J Eur Union L396: 1-849.

ECHA, 2017. Agreement of the Member State Committee on the identification of 4,4'isopropylidenediphenol (bisphenol A) as a substance of very high concern. European Chemicals Agency (ECHA).

Eladak, S., Grisin, T., Moison, D., Guerquin, M.J., N’Tumba-Byn, T., Pozzi-Gaudin, S., Benachi, A., Livera, G., Rouiller-Fabre, V., Habert, R., 2015. A new chapter in the bisphenol a story: Bisphenol S and bisphenol F are not safe alternatives to this compound. Fertil. Steril. 103, 1121. doi:10.1016/j.fertnstert.2014.11.005

EU, 2011. Comission Directive 2011/8/EU of 28 January 2011 amending Directive 2002/72/EC as regards the restriction of use of Bisphenol A in plastic infant feeding bottles. Off. J. Eur. Communities 29-32.

Fan, R., Zeng, B., Liu, X., Chen, C., Zhuang, Q., Wang, Y., Hu, M., Lv, Y., Li, J., Zhou, Y., Lin, Z.Y.W., 2015. Levels of bisphenol-A in different paper products in Guangzhou, China, and assessment of human exposure via dermal contact. Environ. Sci. Process. Impacts 17, 667-73. doi:10.1039/c4em00621f

Gao, L., Zou, J., Liu, H., Zeng, J., Wang, Y., Chen, X., 2013. Determination of bisphenol A in thermal printing papers treated by alkaline aqueous solution using the combination of singledrop microextraction and HPLC. J. Sep. Sci. 36, 1298-1303. doi:10.1002/jssc.201201060

Geens, T., Goeyens, L., Covaci, A., 2011. Are potential sources for human exposure to bisphenol-A overlooked? Int. J. Hyg. Environ. Health 214, 339-47. doi:10.1016/j.ijheh.2011.04.005

Geens, T., Goeyens, L., Kannan, K., Neels, H., Covaci, A., 2012. Levels of bisphenol-A in thermal paper receipts from Belgium and estimation of human exposure. Sci. Total Environ. 435-436, 30-3. doi:10.1016/j.scitotenv.2012.07.001

Gehring, M., Tennhardt, L., Vogel, D., 2004. Bisphenol A contamination of wastepaper, cellulose and recycled paper products, in: Brebbia, C.A., Kungolos, S., Popov, V., Itoh, H. (Eds.), Waste Management and the Environment II. WIT Press, pp. 293-301.

Goldinger, D.M., Demierre, A.-L., Zoller, O., Rupp, H., Reinhard, H., Magnin, R., Becker, T.W., Bourqui-Pittet, M., 2015. Endocrine activity of alternatives to BPA found in thermal paper in Switzerland. Regul. Toxicol. Pharmacol. doi:10.1016/j.yrtph.2015.01.002

Hehn, R.S., 2016. NHANES Data Support Link between Handling of Thermal Paper Receipts and Increased Urinary Bisphenol A Excretion. Environ. Sci. Technol. 50, 397-404. doi:10.1021/acs.est.5b04059

Heijungs, R., Kleijn, R., 2001. Numerical approaches towards life cycle interpretation five examples. Int. J. Life Cycle Assess. 6, 141-148.

Hormann, A.M., Vom Saal, F.S., Nagel, S.C., Stahlhut, R.W., Moyer, C.L., Ellersieck, M.R., Welshons, W. V., Toutain, P.L., Taylor, J.A., 2014. Holding thermal receipt paper and eating food after using hand sanitizer results in high serum bioactive and urine total levels of 
bisphenol A (BPA). PLoS One 9, 1-12. doi:10.1371/journal.pone.0110509

Ikeda, H., Hiraishi, S., Suematsu, K., 1996. Heat sensitive recording material and recording method using the same, Patent Number: 5,876,898, United States Patent.

Jiang, D., Chen, W.Q., Liu, W., Chertow, M., 2017. Inter-Sectoral Bisphenol A (BPA) Flows in the 2012 Chinese Economy. Environ. Sci. Technol. 51, 8654-8662. doi:10.1021/acs.est.7b01986

JRC-IHCP, 2008. European Union Risk Assessment Report: 4, 4'-isopropylidenediphenol (Bisphenol-A). Eur. Union 2008, 201-245. doi:10.2788/40195

Kinch, C.D., Ibhazehiebo, K., Jeong, J.-H., Habibi, H.R., Kurrasch, D.M., 2015. Low-dose exposure to bisphenol A and replacement bisphenol S induces precocious hypothalamic neurogenesis in embryonic zebrafish. Proc. Natl. Acad. Sci. U. S. A. 112, 1475-80. doi:10.1073/pnas.1417731112

Konkel, L., 2013. Thermal Reaction: The Spread of Bisphenol S via Paper Products. Environ. Health Perspect. 121, a76-a76. doi:10.1289/ehp.121-a76

Lawrywianiec, M., Smajdor, J., Paczosa-Bator, B., Piech, R., 2017. High Sensitive Method for Determination of the Toxic Bisphenol A in Food/Beverage Packaging and Thermal Paper Using Glassy Carbon Electrode Modified with Carbon Black Nanoparticles. Food Anal. Methods. doi:10.1007/s12161-017-0945-8

Li, Y., Shen, S., Liu, Y., Gao, J., 1999. Kinetics of 4,4'-diaminodiphenylmethane curing of bisphenol-S epoxy resin. J. Appl. Polym. Sci. 73, 1799-1803. doi:10.1002/(SICI)10974628(19990829)73:9<1799::AID-APP23>3.0.CO;2-Y

Liao, C., Kannan, K., 2011a. Widespread occurrence of bisphenol A in paper and paper products: implications for human exposure. Environ. Sci. Technol. 45, 9372-9. doi:10.1021/es202507f

Liao, C., Kannan, K., 2011b. High levels of bisphenol A in paper currencies from several countries, and implications for dermal exposure. Environ. Sci. Technol. 45, 6761-8. doi:10.1021/es200977t

Liao, C., Liu, F., Kannan, K., 2012. Bisphenol s, a new bisphenol analogue, in paper products and currency bills and its association with bisphenol a residues. Environ. Sci. Technol. 46, 651522. doi:10.1021/es300876n

Liu, P., Cao, X., Zhao, C., Liu, H., 2013. Migration and transformation of bisphenol A in thermal receipt paper. China Environ. Sci. 33, 3-7.

Lu, S.-Y., Chang, W.-J., Sojinu, S.O., Ni, H.-G., 2013. Bisphenol A in supermarket receipts and its exposure to human in Shenzhen, China. Chemosphere 92, 1190-4. doi:10.1016/j.chemosphere.2013.01.096

Lunder, S., Andrews, D., Houlihan, J., 2010. BPA Coats Cash Register Receipts. Environmental Working Group, Washington, DC, USA.

Mendum, T., Stoler, E., VanBenschoten, H., Warner, J.C., 2011. Concentration of bisphenol A in thermal paper. Green Chem. Lett. Rev. 4, 81-86. doi:10.1080/17518253.2010.502908

Miljøstyrelsen, 2011. Migration of bisphenol A from cash register receipts and baby dummies. Survey of chemical substances in consumer products No. 110, Miljøstyrelsen (Danish EPA), 


\section{Copenhagen, Denmark.}

Molina-Molina, J.M., Amaya, E., Grimaldi, M., Sáenz, J.M., Real, M., Fernández, M.F., Balaguer, P., Olea, N., 2013. In vitro study on the agonistic and antagonistic activities of bisphenol-S and other bisphenol-A congeners and derivatives via nuclear receptors. Toxicol. Appl. Pharmacol. 272, 127-136. doi:10.1016/j.taap.2013.05.015

Morin, N., Arp, H.P.H., Hale, S.E., 2015. Bisphenol A in Solid Waste Materials, Leachate Water and Air Particles from Norwegian Waste Handling Facilities: Presence and Partitioning Behavior. Environ. Sci. Technol. doi:10.1021/acs.est.5b01307

MPCA, 2014. BPA and BPS in Thermal Paper: Results of Testing in Minnesota Hospitality Industry. Minnesota Pollution Control Agency (MPCA), MN, USA.

Ndaw, S., Remy, A., Jargot, D., Robert, A., 2016. Occupational exposure of cashiers to Bisphenol A via thermal paper: urinary biomonitoring study. Int. Arch. Occup. Environ. Health 89, 935946. doi:10.1007/s00420-016-1132-8

NITE, 2003. National Institute of Technology and Evaluation. Summary of the Interim Report Bisphenol A. National Institute of Technology and Evaluation, Tokyo, Japan.

Östberg, T., Noaksson, E., 2010. Bisfenol A in svenska kvitton. Analysresultat. Institutet för tillämpad Grön kemi, Jegrelius (Institute for Applied Green Chemistry). Östersund, Sweden.

Pivnenko, K., Astrup, T.F., 2016. The challenge of chemicals in material lifecycles. Waste Manag. 56, 1-2. doi:10.1016/j.wasman.2016.08.016

Pivnenko, K., Eriksson, E., Astrup, T.F., 2015a. Waste paper for recycling: Overview and identification of potentially critical substances. Waste Manag. 45, 134-142. doi:10.1016/j.wasman.2015.02.028

Pivnenko, K., Laner, D., Astrup, T.F., 2016a. Material Cycles and Chemicals: Dynamic Material Flow Analysis of Contaminants in Paper Recycling. Environ. Sci. Technol. 50, 12302-12311. doi:10.1021/acs.est.6b01791

Pivnenko, K., Olsson, M., Götze, R., Eriksson, E., Astrup, T.F., 2016b. Quantification of chemical contaminants in the paper and board fractions of municipal solid waste. Waste Manag. 51, 4354. doi:doi:10.1016/j.wasman.2016.03.008

Pivnenko, K., Pedersen, G.A., Eriksson, E., Astrup, T.F., 2015b. Bisphenol A and its structural analogues in household waste paper. Waste Manag. 44, 39-47. doi:10.1016/j.wasman.2015.07.017

Püssa, T., 2016. Presence of Bisphenols (BPA and BPS) in thermal paper receipts in Estonia. Tartu, Estonia.

Rajasärkkä, J., Koponen, J., Airaksinen, R., Kiviranta, H., Virta, M., 2014. Monitoring bisphenol A and estrogenic chemicals in thermal paper with yeast-based bioreporter assay. Anal. Bioanal. Chem. 406, 5695-5702. doi:10.1007/s00216-014-7812-x

Rocha, B.A., Azevedo, L.F., Gallimberti, M., Campiglia, A.D., Barbosa, F., 2015. High Levels of Bisphenol A and Bisphenol S in Brazilian Thermal Paper Receipts and Estimation of Daily Exposure. J. Toxicol. Environ. Health. A 78, 1181-8. doi:10.1080/15287394.2015.1083519 
Rochester, J.R., Bolden, A.L., 2015. Bisphenol S and F: A Systematic Review and Comparison of the Hormonal Activity of Bisphenol A Substitutes. Environ. Health Perspect. 123, 643-650. doi:10.1289/ehp.1408989

Russo, G., Barbato, F., Grumetto, L., 2017. Monitoring of bisphenol A and bisphenol S in thermal paper receipts from the Italian market and estimated transdermal human intake: A pilot study. Sci. Total Environ. 599-600, 68-75. doi:10.1016/j.scitotenv.2017.04.192

Schabel, S., 2011. Mineral oils and other volatile contaminants in printed paper and board and measures for removal in recovered paper processing, in: Wang, L., Kuang, S., Hou, Q., Cao, C., Si, C., Zhang, H. (Eds.), Proceedings of the Sixteenth International Symposium on Wood, Fiber and Pulping Chemistry. China Light Industry Press, Tianjin, China.

Schreder, E., 2010. On the Money: BPA on Dollar Bills and Receipts. Safer Chemicals, Healthy Families. Washington Toxic Coalition, DC, USA.

State of Connecticut, 2013. An act prohibiting the use of Bisphenol-A in thermal paper. Public Act No. 11-222, State of Connecticut, CT, USA.

Thayer, K.A., Taylor, K.W., Garantziotis, S., Schurman, S., Kissling, G.E., Hunt, D., Herbert, B., Church, R., Jankowich, R., Churchwell, M.I., Scheri, R.C., Birnbaum, L.S., Bucher, J.R., 2015. Bisphenol A, Bisphenol S, and 4-Hydroxyphenyl 4-Isoprooxyphenylsulfone (BPSIP) in Urine and Blood of Cashiers. Environ. Health Perspect. 124, 437-444. doi:10.1289/ehp.1409427

US EPA, 2014. Bisphenol A alternatives in thermal paper. United States Environ. Prot. Agency, Washington, DC, USA.

Usman, A., Ahmad, M., 2016. From BPA to its analogues: Is it a safe journey? Chemosphere 158, 131-142. doi:10.1016/j.chemosphere.2016.05.070

von Goetz, N., Pirow, R., Hart, A., Bradley, E., Poças, F., Arcella, D., Lillegard, I.T.L., Simoneau, C., van Engelen, J., Husoy, T., Theobald, A., Leclercq, C., 2017. Including non-dietary sources into an exposure assessment of the European Food Safety Authority: The challenge of multisector chemicals such as Bisphenol A. Regul. Toxicol. Pharmacol. doi:10.1016/j.yrtph.2017.02.004

Yalcin, M.S., Gecgel, C., Battal, D., 2016. Determination of Bisphenol A in Thermal Paper Receipts 3, 167-174. doi:10.18596/jotcsa.21345.

Zech, J., 2015. Stable Isotope Dilution Assay of Bisphenol A, Bisphenol F and Bisphenol S from Thermal Paper Using High-Performance Liquid Chromatography-Tandem Mass Spectrometry. Dtsch. Leb. 111. 